\title{
Notes on the vocalizations of Pin-striped Tit-babbler (Macronus gularis)
}

Peter Boesman

In the following we briefly analyze and compare voice of the different races of Pin-striped Titbabbler (Macronus gularis). We also try to quantify the extent of any vocal differences using the criteria proposed by Tobias et al. (2010), as a support for taxonomic review. We have made use of sound recordings available on-line from Xeno Canto (XC).

Our main interest is to compare Philippine race woodi with other races, as voice description in HBW suggests some vocal difference (Collar et al. 2016)

There are only a few recordings available of race woodi:

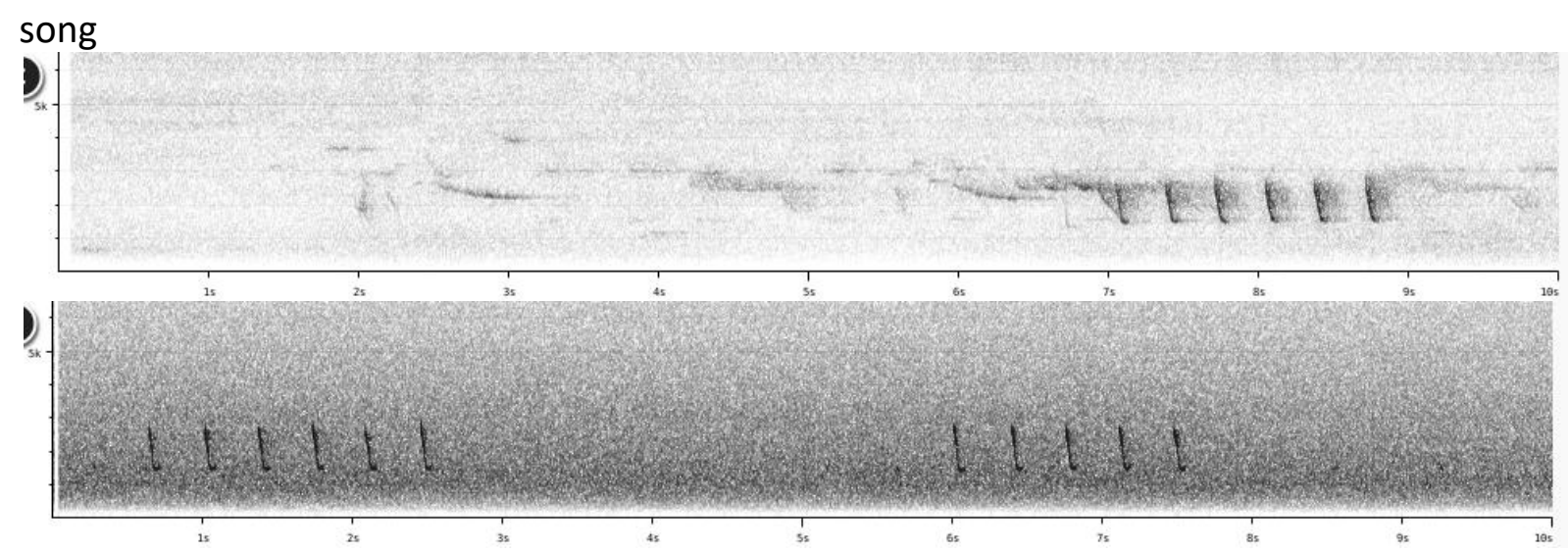

This is very similar or identical to other races:

Malaysia

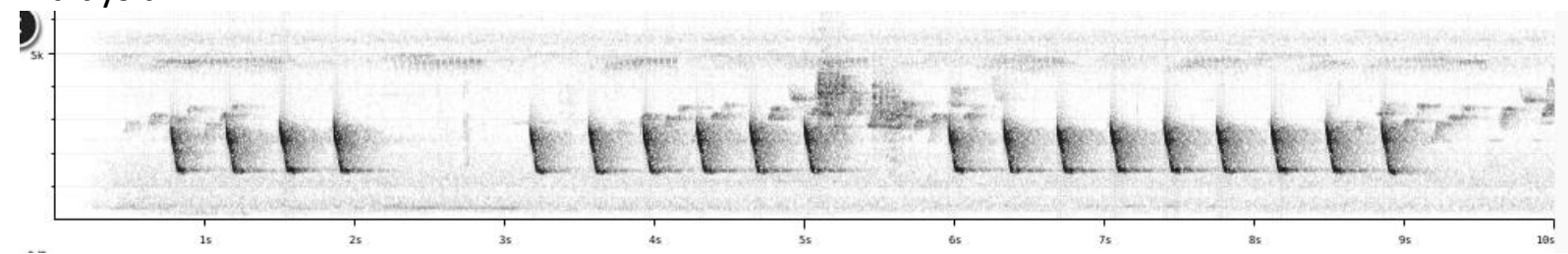

Nepal

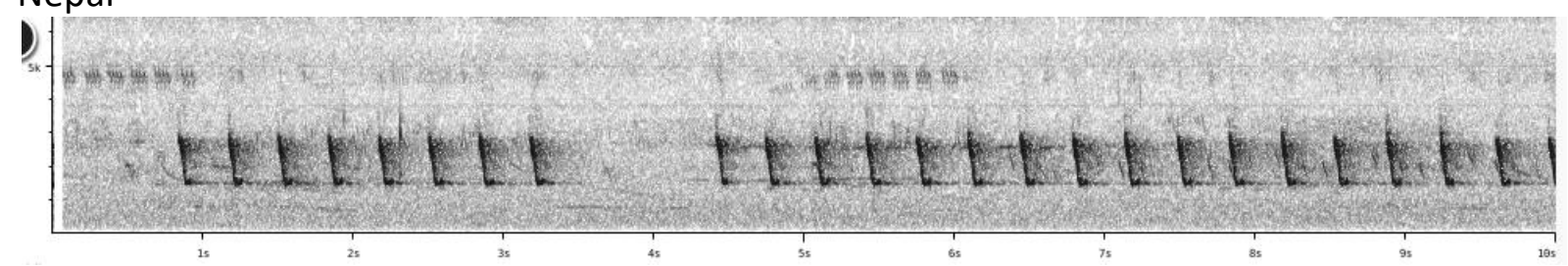

All basic sound parameters are very similar (pace, note length, freq. range..).

A single recording of call notes of woodi does not have obvious matching recordings from elsewhere, but then again there are very few recordings available of call notes. 
Based on available evidence, there is thus no clear indication of vocal difference.

This note was finalized on 8th April 2016, using sound recordings available on-line at that moment. We would like to thank in particular the many sound recordists who placed their recordings for this species on XC.

\section{References}

Collar, N. \& Robson, C. (2016). Pin-striped Tit-babbler (Macronus gularis). In: del Hoyo, J., Elliott, A., Sargatal, J., Christie, D.A. \& de Juana, E. (eds.). Handbook of the Birds of the World Alive. Lynx Edicions, Barcelona. (retrieved from http://www.hbw.com/node/59482 on 8 April 2016).

Tobias, J.A., Seddon, N., Spottiswoode, C.N., Pilgrim, J.D., Fishpool, L.D.C. \& Collar, N.J. (2010). Quantitative criteria for species delimitation. Ibis 152(4): 724-746.

\section{Recommended citation}

Boesman, P. (2016). Notes on the vocalizations of Pin-striped Tit-babbler (Macronus gularis). HBW Alive Ornithological Note 266. In: Handbook of the Birds of the World Alive. Lynx Edicions, Barcelona. (retrieved from http://www.hbw.com/node/1251707 on 5 October 2016). 